\title{
The Determinants of Investment Strategy: An Empirical Assessment of Behavioural Factors in the Omani Context
}

\author{
Gopalakrishnan Chinnasamy*, Araby Madbouly Ahmed Hussein, Stephen Aro-Gordon \\ Muscat College, Sultanate of Oman
}

\section{ARTICLE INFO}

\section{Article history:}

Received 13 September 2019

Revised 30 October 2019 \& 02

December 2019

Accepted 11 December 2019

Published 07 January 2020

\section{Keywords:}

Behavioral finance

Herding factors

Heuristics

Investment decisions

Muscat securities market

Prospect factors

\begin{abstract}
This paper examines the behavioural factors influencing investment decisions and strategy in the Sultanate of Oman. Investors' decision-making process is thought to be influenced by a wide range of factors directly or indirectly (Kusev et al. 2017). The rational approach considers only the mathematical results thereby failing to recognize the investor's related psychological and sociological factors, categorized in the paper as heuristic factors, prospect factors and herding factors. This study attempts to identify the behavioural factors that influence individual investors' decision in the Muscat Securities Market (MSM). Specifically, the study was designed to identify the factors which are mostly influencing the investment decisions of investors. Employing descriptive research design; data were collected from individual investors who had traded in the MSM during the fourth quarter of 2018. The primary collected through structured questionnaire and the secondary data is collected from various sources from stock brokers, Journals and other sources respectively. The simple random sampling technique was applied and the collected data covering 16 variables of behavioural factors were analyzed using the factor analysis, principal component analysis with varimax rotation, and Analysis of Variance tools. The anchoring, mental accounting, movement of prices, volume of trade and market information factors emerged as the five principal determinants of investment strategy are the major findings of the study. The results might make investors and advisors to understand the optimal ways to improve on strategy for structuring optimum portfolio selection and how far this can be optimised further in terms of managing their investment behaviour.
\end{abstract}

\section{Introduction}

Investment decision is a complex process which requires different steps and includes several analyses. Modern investment decisions result from diverse and complex models based on expected risk and expected return related with an investment, and risk-based capital asset pricing models, Efficient Market Hypothesis and Modern Portfolio Theory (Gopalakrishnan et al, 2019). The idea that the rationality of the participants in the market and the available information reflects the stock-market prices form the basis of most of the financial theories and asset pricing techniques such as the discounted dividend, cash flow, and abnormal earnings models (Kusev et al. 2017). The main intention of rational investors is assumed to be solely to maximise their wealth. However, due to increasing uncertainties, rationality loses its 'absolute valuation' characteristics in a dynamic market. Thus, the emergence of irrational factors, anomalous or inconsistent behaviour of observed in many stock markets has led to the essence of behavioural finance approach to investment management (Dowie, G., \& Willows, G. 2016).

Over the period, behavioural finance has become a new phenomenon and it has become essential approach in investment decision making process. It can be defined as "a rapidly growing area that deals with the influence of psychology on the behaviour of financial practitioners" (Shefrin, 2002, p.18). It is a new area which seeks to cover up psychological and behavioural theory with orthodox economic and finance to gives an insight why investors make financial decision irrationally. Behavioral finance is justified by the need to identify why investors' buy, hold, or sell

* Corresponding author.

E-Mail address: gopalakrishnan@muscatcollege.edu.om 
securities without using conventional fundamental approaches in their investment or portfolio selection decisions. According to Shefrin (2002), "behavioural finance is how the psychology of an investor affects financial decision making in the market". "Behavioural finance initiates to understand how the investors make decision on emotions rather than the fundamentals" (Frieder, 2004). Athur (2014) stated that the investors' decisions are associated with the biases like "Representativeness", "overconfidence", "mental accounting", "anchoring", "herding" and "regret aversion". Hence, the behavioural finance is seen as a scientific approach on the emotional, psychological and social applications by the investors and the trends of the market price. It influences the decision making of an individual investors, group and entities (Singh \& Shivaprasad, 2018).

\section{Problem Statement}

The emerging figures from Oman's capital market show some amount of inconsistency in the trading pattern in the Muscat Securities Market (MSM) over the years. For example, while there has been "mixed" upward and downward trend in (MSM) 30 index in 2017 and 2018, the same index has recorded a downward trend of $15.21 \%$ in 2018 when compared to 2017. On the other hand, the market capitalization and turnover movements recorded the increasing trend in 2018. This fluctuating scenario continued from past five years (MSM, 2018). The decision-making process is traditionally associated with the rational approach. The fundamental concept of rationality was based on some fundamental and technical approaches as well as some relevant financial theories. The main aim of each individual investor is to maximise his/her return. But in real scenario the return varies due to some fear, emotions and belief (Rehik, 2014). Market experts denotes these variations as financial anomalies such as fundamental, calendar and technical abnormalities (Razek, 2011). It is found that these variances affect robust operation of the capital market due to lack of rationality approach involving the mathematical approach in taking investment decision. These challenges in the traditional investment approach provide added impetus to the behavioural finance discipline which recognises the emotions, psychology of individual investors in investment decision (Rehik, 2014). The economy of the countries highly relies on the stock market operations usually determined by the investors' decisions. Hence, the decision-making ability of each individual investor contributes to the growth of any country. To understand and support the investors' decision to enhance Oman's economy, it is therefore vital to explore the behavioural factors that influence the investment decision of an investor at the MSM and how these factors play a crucial role in their investment performance. Therefore, this study is an attempt to examine the behavioural factors that influence the individual investors' decisions in the MSM and to build an appropriate risk model for portfolio selection.

\section{Research objectives}

The study attempts to identify the behavioural factors that influence individual investors' investment decision in the MSM. Specifically, the study was designed to:

- Identify the prospect factors influencing the investment decisions of investors in the MSM;

- Determine the heuristic factors influencing the investment decisions of investors in the MSM; and

- Find out the herding factors influencing the investment decisions of investors in the MSM.

\section{Contribution to knowledge}

Despite the Nobel Prize-winning "efficient market theory" idea, there is considerable debate over the role of human behavior (irrational sentiments or emotions) in global investment decision making processes (Desai, 2019). Behavioural finance has therefore become crucial to investment science and for helping investment practitioners to better manage risk perception, thereby promoting the overall investment environment. It could be observed from the previous studies such as Radha et al (2014) and Al Balushi (2019) that academic research in Oman context has been rather restricted to behavioural factors in Islamic finance and SME context; there is no known previous study that has examined the subject of empirical behavioural finance in the relatively broader context of the Oman's main bourse, the MSM. Country-specific studies - for example, India (Tripathi and Chattopadhyay, 2013), Pakistan (Mahmood et al, 2016), Kenya (Arthur. 2014), Tunisia (Boussaidi, 2013) Sri Lanka (Kengatharan, 2014), and South Africa (Lowies et al, 2013) were conducted in many jurisdictions as part of academic support to capital market development in various countries. Hence, the key contribution to the literature in this paper is the attempt to fill the gap in the dearth of information on identifying the empirical behavioural factors influencing investment decisions in Oman, with emphasis on the emerging scenario in the country's capital market. The present study might be the first major 
contribution to empirical behavioural finance literature in Oman, which promises to trigger further studies in the field that would enhance the country's investment market - companies, institutional investors, traders, bankers, analysts, researchers - as Oman seeks to transit towards a more diversified post-oil economy.

The value of this study can be seen from two key perspectives. First, the approach of behavioural finance is relatively new when it is compared to other traditional approaches especially in the Oman context. It is hoped that the present paper would bring out opportunities for students, scholars, and investment practitioners to understand more practical as well as theoretical knowledge of behavioural finance, by providing evidence-based information to the investors. Secondly, Oman economy is being re-structured and envisioned to encourage investors across priority sectors such as tourism, information technology, and manufacturing. Hence, this study trying to identify the factors which influence the decision-making ability of investors in the MSM especially in the behavioural aspects.

The paper is divided into five sections. After this Introduction as section 1, section 2 contains a review of related literature on the subject including a synthesis of the conceptual framework and research hypotheses formulated to guide the research. The methods adopted for conducting the research comes in section 3, followed by the analysis of the data and results in section 4, focused on the four behavioural factors selected for investigation in the MSM. The paper ends in section 5 by highlighting key implication of the current findings and areas for possible future research, particularly in Oman context.

\section{Literature Review and Conceptual Framework}

This section reviews the existing body of knowledge that might be helpful to understanding the science of behavioural finance in the Omani context. The literature review suggests that there is some continuous debate over the actual nexus between financial asset investment and a country's real economic growth. Yet, an oil-dependent economy like the Sultanate of Oman that is envisioning a well-diversified post-carbon economy would need a robust and inclusive capital market to finance the requisite capital investment projects targeted at the sustainable well-being of the people (Desai, 2019). In this regard, this section has covered some established knowledge regarding the potential roles of behavioural finance theories such as heuristics, anchoring, prospect, and herding, among others, in investors' decision-making and strategy choices. Being a country-specific study, this section has also highlighted what might be the empirical research status of the subject in the Omani context, followed by the resultant conceptual framework developed for the present study.

\section{The continuing search for real evidence of the linkage between stock-market and real growth}

Investment strategy is an essential for the financial economists and the investors to do investment or make a constructive decision to earn an abnormal return in the market. The investors' perception and the behaviour of the market are the essential factors of the market analysts and scholars (Singh, 1997). The empirical evidences are inadequate to identify the linkage between the economic growth and the development of the stock market. There is a positive correlation between real economic growth particularly in the developing countries and the stock market activities (Lowies et al, 2013; Chodorow-Reich et al, 2019). The management approach in the selection of an optimum portfolio remain critical issue for investors, analysts, and academicians. Markowitz (1952) assumes that investors expected highest return with the minimum risk taking effort in their investment decisions; this structure has been a routine empirical and theoretical developments. Taking into consideration the decision-makers' behaviour on the aspects of risk, uncertainty, minimum risk intention, high yield expectation raised the question regarding which level of behaviour on investment decisions can be compared in the way of low behaviour versus high behaviour (Coelho 2014).

\section{The role of heuristics and anchoring in investment behaviour}

According to Lutje (2009), behaviour finance is subject to several cognitive illusions of human decision making activities and psychology. Ritter (2003) states that the heuristics as the kind of rule that makes decision very simple at the time of difficult and complex situations and unexpected environments. The heuristics approach is reducing the difficulty in assumptions and predictions regarding the values in taking simple decisions (Kahneman \& Tversky, 2004). Heuristics are quite easy and useful when the time constraints are explicit (Waweru et al., 2008) but sometimes it leads to biased decisions. The heuristics approach rarely explains how this process reduces the amount of efforts are required during the judgments in a simple way of taking required decisions (Shah \& Oppenheimer, 2008). 
According to Shefrin (2002) the overconfidence arises in the area of their knowledge and the capacities. Overconfidence may arise when analysts overweigh their private information and under-weigh public information (Friesen and Weller, 2006). Overconfidence may be predicted via models use past success in forecast accuracy of a given analyst as the good prediction for short time by the analysis lead to inaccuracy and to take additional risks by deviating from the consensus (Gervais and Odean, 2001; Daniel et al., 1998). The overconfidence can be shown if overreaction to private information and underreaction to public information are observed before and after the public announcement (Bessie`re \& Elkemali, 2013)

The anchoring effect can be mentioned as heuristics applied when decision is taken under uncertain situations (Kahneman \& Tversky, 2004). According to Mochon and Frederick (2013), "Anchoring is the term applied to situations in which numeric judgments assimilate towards a previously encountered standard". The anchoring effect can be explained via two mechanisms which are semantic anchoring mechanism and numeric anchoring mechanism (Mussweiler and Strack, 2001; Sleeth-Keppler, 2013). Numeric anchoring occurs in the case of existence of unrelated numbers in the short-term memory (Wilson et al., 1996). Semantic anchoring mechanism supposes that "numeric anchoring effect occurs due to a subject's selective search for anchor consistent semantic knowledge about an estimation target, and in case when the evoked knowledge is irrelevant, no anchoring effect including pure numeric anchoring will occur" (Mussweiler and Strack, 2001). According to Rekik and Boujeibene (2014) the adjustment is typically inefficient when the financial prediction is applied by starting from an initial figure is adjusted with the expected yield.

\section{The prospect theory - loss and regrets aversion}

The prospect theory represents an important model in the area of decision making during uncertainties. The prospect approach focuses on empirical and observable decision behavior (Thaler, 1985). A prospect describes the complete range of possible outcomes of a decision and their respective probabilities (Jacob \& Ehret, 2006). Identifying from the hypothesis of planned rationality, this theory suggests that investor will elevate the variable factors related risk levels at different environment depending on how they make an investment decision making (Holmes et al., 2011). To express the risk preferences in the managerial approach explain the prospect theory is done on individual decision making pattern (Miller \& Chen, 2004). The prospect theory is dependent with the central and innovating role approach. In this theory is observed through risk attitude, uncertainty, sign of outcomes; and reducing the sensitivity outcomes as the investors are sensitive in nature (Schmidt \& Zank 2012). This theory argues that the investors/people are more sensitive to losses than to gain when they make decision under risky situations (Wakker, 2005). The loss aversion affects the positive decision making approaches among the investors while taking an investment decision. According to Kangatharan (2014), investors may have various opinions and approaches on the behaviour of price changes based on the present and future information spread in the market if there is a positive opinion of behavioural finance.

\section{Suspension of rational personal judgement through herding behaviour}

The herding is obviously ignoring the personal judgment and follows the approach and the behaviour of other investors to do the investment decision (Nofsinger and Sias, 2008; Bikhchandani and Sharma, 2001) or following the trend in previous trade (Avery and Zemsky, 1998) resulted from excessive agreement in the prediction of the analyst (DeBondt and Forbes, 1999) which form a correlated behavior of the investors (Sias, 2004).

The rational and irrational motives are the driving force among investors is the behaviour of herding, it can be stated that this creates stress by pushing the prices through market volatility (Blasco et al., 2012). While evaluating the investments decision affects by representativeness heuristic approach elaborate the overreaction (Frieder 2004; Alwathainani 2012, Boussaidi 2013). Guo (2013) adopts an analytical approach in his study of securities market so as to identify the survival of representativeness in rational traders with irrational traders' competition. The available techniques are successful in identifying to face difficult tasks. The financial market inefficiency causes the herding effect is usually identified as speculative bubbles. Hirschey \& Nofsinger (2008) stated that investor herding is the movement of a large group of investors or group of industry at the same point of time. Furthermore, the human beings are socially dependent in nature and on each other while making decision regarding to their investment (Singh. J. E., \& Shivaprasad, 2018). Bikhchandani and Sharma, (2001) distinguish between the spurious and intentional herding. The former (spurious herding) occurs where investors receive similar data set which lead to have the same decision from all, this type may lead to an efficient outcome. The later (intentional herding) occurs where investors 
intentionally act exactly like others, this may lead to inefficient outcomes like fragile markets, excess volatility and systemic risk.

Scholars differentiate between the rational or irrational herding behaviour. The rational herding behavior can be shown where analysts are more likely to herd when they are characterized by high reputation or low ability (Graham, 1999). Furthermore, herd behavior can be a rational choice if investors have short as they may herd on the same information trying to learn what other informed investors know (Froot et al., 1992). The implication of informational cascades models may also lead to rational herding. In this regard, (Bikhchandani et al., 1992) argue that informational cascades model takes place when individuals do not give any consideration to their own information. However, some experimental research concluded that herding in the form of an informational cascade might be impossible when the subjects are trading for informational reasons. Thus, herding is said to rarely occurs, although in some cases subjects follow a contrarian strategy or choose to ignore private information (Avery and Zemsky, 1998; Cipriani and Guarino, 2005). Irrational herding behavior may resulted from psychological reasons (Spyrou, 2013) or scarcity of information (Baddeley et al., 2004). Irrational herding investors can be called noise traders (Black, 1986) as they act on noise and whose trading behavior suffers from systematic biases. The irrational herding may arise within sequential choice framework models, when people take their decisions following others with ignorance for the influence of non-salient aspects of such decisions (Simonsohn and Ariely, 2008). There are two methods can be used to measure the herding in financial markets; they are the measurement that rely on microdata or the measurement using aggregate price and market activity data and investigate herding toward the market consensus (Lakonishok et al., 1992; Sias, 2004).

\section{Empirical evidence of behavioural finance factors in the Omani context}

Motivated by the relative dearth of academic literature in Oman context, this study is designed to identify the behavioural factors influencing the investment decisions of investors in the country's main bourse, Muscat Securities Market (MSM). Rational theory suggests that human decisions are based on rational, logical, reasonable thinking, economic markets have manifested such irrationality that could possibly be explained in the perhaps more complex realm of psychology or human behaviour. As it is noted earlier, a range of country-specific studies has been undertaken across the globe. For example, using information gathered from experts and laymen in four metropolitan cities of India, namely Mumbai, Delhi, Chennai and Kolkata, Tripathi and Chattopadhyay (2013) investigated the behavioural aspects of financial decision making variables like faith, knowledge, availability of information, uncertainty, predictability of future outcome, complexity of product, and transparency that define risk perception of individual investor in equity mutual fund. The study documented six components describing riskiness of investment, namely risk of potential adverse returns, extent of control on the outcome, self-regulation, voluntary risk taking, financial consciousness, and transparent dealings. Discriminant analysis showed diverse weights assigned to each of the factors by experts and laymen, thus confirming the influence of behavioural elements in the Indian market. Similarly, Mahmood et al (2016) investigate the impact of Heuristics, Prospects, and Herding on investment performance of individual investors in Pakistani stock market using primary data. The study revalidates irrational behavior as the product of certain cognitive and/or emotional biases in investment decision-making mentality. Specifically, Heuristics and Herding were found to be positively related to investment performance, but Prospect is negatively related in the Pakistani context.

Few studies appear to have been conducted in Omani context. Al Balushi et al (2019) examined the determinants of Islamic financing decision in Oman. The researchers found that while small and medium-scale enterprises (SME) owner-managers' Islamic financial knowledge and personal characteristics do influence their intention to adopt Islamic finance, firms' characteristics have had no significant influence on Islamic investment decisions. However, their contribution had some limitations in terms of the study's findings generalizability to large and public firms, as the sample includes owner-managers of SMEs only, thus pointing to the need to investigate other behavioural factors, which were not previously explored in Oman context. Little or no emphasis has been given to behavioural dimensions investment strategy in the MSM, the main thrust of the present study. Radha et al (2014) conducted a primary study to try to understand investment behavior of Omani households. The study documents 25 key factors influencing choice of investment channels in Oman. The study finds no significant support for rational decision making among the Omani households. Specifically, there is no significant relation between choice of investment avenues and the investor's educational, occupational level and work experience. Interestingly, the study found 'Market Trend' and 'Rumors' to be the most influencing while 'Government Policies' and 'Dependent Behavior' are the least influencing in Oman, as far as the retail investment market was concerned.

Whereas behavioural finance studies were conducted in several other emerging securities markets such as India (Tripathi and Chattopadhyay, 2013), Pakistan (Mahmood et al, 2016), Kenya (Arthur. 2014), Tunisia (Boussaidi, 
2013) Sri Lanka (Kengatharan, 2014), and South Africa (Lowies et al, 2013), to mention few, it might be clear from the above review of the literature, that empirical knowledge of behavioural attributes of capital market investment in the Omani context remains rather sparse. It would seem that the main weakness of most previous studies was the failure to subject critical behavioral assumptions such as Heuristics, Prospects, and Herding, among others, to empirical investigation in the country-specific context of the Sultanate of Oman, a growing economy in the Gulf region, strategically located for enhanced international trade. Drawing notably from the Pakistani contextual study of Mahmood et al (2016), it is hoped that the findings from an empirical research in the Omani context could advance the behavioural finance literature that could improve portfolio risk management theory, practice and policy, particularly in developing economies.

Thus, despite the Nobel Prize-winning "efficient market theory" idea, there is considerable debate over the role of human behavior (irrational sentiments or emotions) in global investment decision making processes (Desai, 2019). It could be observed from the previous studies such as Radha et al (2014) and Al Balushi (2019) that academic research in the Omani context has been rather restricted to behavioural factors in Islamic finance and SME context; there is no known previous study which has examined the subject of empirical behavioural finance in the relatively broader context of the MSM. Hence, the key contribution to the literature in this paper is the attempt to fill the gap in the dearth of information on identifying the empirical behavioural factors influencing investment decisions in the Sultanate of Oman, with emphasis on the emerging scenario in the country's securities market.

\section{Research Model}

The above literature review might suggest that the emerging academic consensus is that investors' decisions regarding their investments in the capital market are influenced by behavioural factors. Given the emerging role of the Sultanate of Oman as a strategic market in the Gulf Cooperation Council (GCC) region in particular, and global tourism market generally, this attempts to explore the behavioural factors influencing investors' decisions at the country's flagship stock exchange - the MSM. The main objectives of this study is to examine the relationship between heuristic factors, prospect factors, herding factors, market factors and investment decision of behavioural finance. This can be explored through the conceptual model presented in Figure 1.

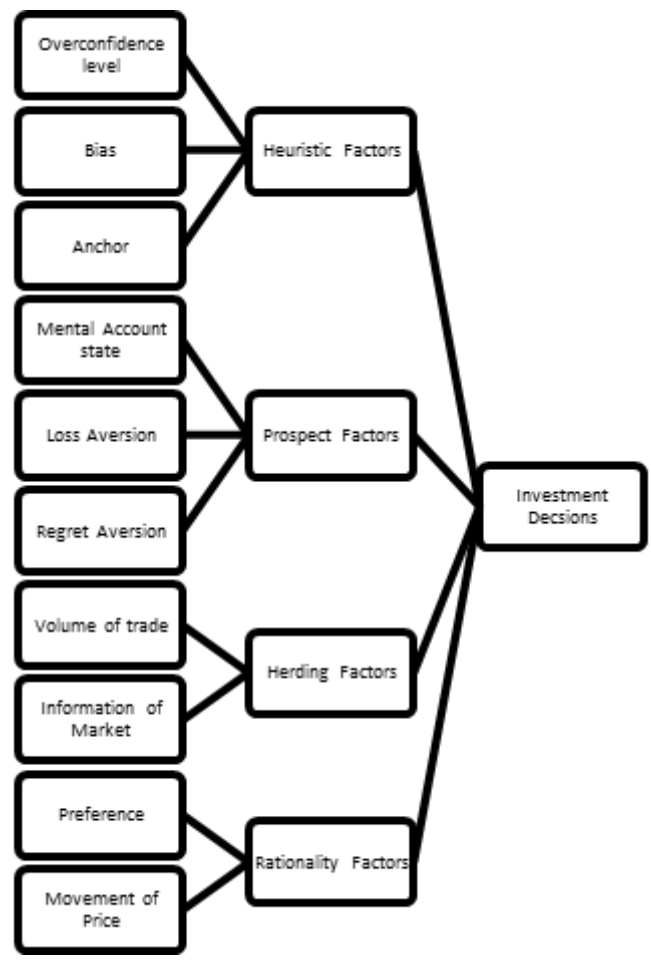

Source: Developed by the authors from the literature (notably, Mahmood et al, 2016)

Figure 1. Conceptual Framework 


\section{Hypotheses of the study}

The following hypotheses were formulated to guide the requisite analysis in the present study.

$H \_0$ : There is no significant influence of selected factors on investors' investment decision.

H_1: There is significant influence of selected factors on investors' investment decision.

\section{Research Methodology}

This section highlights the major research techniques adopted in conducting the empirical study of the human psychological factors that might be prevalent in the Omani investment market. Such key aspects such as the research design, sampling and sources of data, the main analytical procedures and tools, as well as some possible limitations of study have been covered in the following paragraphs.

\section{Research Design}

The present study employed descriptive research design approach. It was necessary to decide the respondents, data collection approach, tools and techniques which justify the data collection process (Oso \& Onen, 2009). Consequently, the population of the study was taken to be the individual investors trading in the MSM in the period of fourth quarter of 2018.

\section{Sources of Data}

The structured questionnaire was used to collect the primary data from the respondents and the secondary data were gathered from various authenticated websites, refereed journals and books. The field survey followed a drop and pick up approach of data collection method to collect the data from sampled respondents.

\section{Sampling and tools for analysis}

The drop and pick up method of data deployed for the study was deemed suitable to ensure a high rate of response from the respondents (Kothari, 2011). On an average three questionnaires were dropped in all the seventeen stockbroking companies licensed and actively involved in the MSM, located in the Sultanate of Oman. The dropped questionnaire is collected by one of the researchers after ten working days from the stock-broking companies. Hence, the total number of sample used for the study was 51 . The collected data was analysed using descriptive statistics and factor analysis using Statistical Package for the Social Science (SPSS) version 25.0.

\section{Factor Analysis}

The research problem covers the psychological factors of investment behaviour and its association with investment decision and strategy. Four behavioural factors comprising 14 variables were ascertained using factor analysis. Five point Likert scales were used to collect the primary data from the respondents. Factor analysis is used in multivariate statistics and has a vital task in identifying which variables clump together to form other variables. There are various methods used to conduct factor analysis, whereas this study employs principal component analysis with varimax rotation.

\section{Limitations of the study}

The study collects the relevant data from 51 respondents only due to time constraints; but it was spread across seventeen stock-broking companies licensed and actively involved in the MSM (located in the country's capital city, Muscat) to collect the valid and unbiased information. The investors' hesitancy in providing complete information about their investments might question the data's validity. 


\section{Data Analysis and Interpretation}

This section presents the results of the data analysis regarding the behavioral aspects of investment decisions and strategy in the Oman context. First, the demographics of the respondents are given. This is followed by hints on the level of data adequacy based on Kaiser-Meyer-Olkin (KMO)'s and Bartlett's tests in order to give some assurance regarding data validity. Thereafter, using the analytical tools of principal component analysis, scree plot test, and varimax rotation, the section proceeds to critically evaluate the impact of behavioural factors in the context of two managerial domains - (i) investment decisions and (ii) investment strategy - and ends with a summary of the key findings.

\section{Demographic profile of respondents}

The collected data from respondents through questionnaire were analysed using SPSS software to test statistically to the subject matter of the study. Table 1 displays the demographic profile of respondent investors. Majority was $(76.5 \%)$ married, $(43.2 \%)$ in the middle-age $35-44$ years, and (51\%) graduate investors.

Table 1. Demographic Profile of an Investor

\begin{tabular}{|c|c|c|c|c|c|}
\hline Variables & & Percentage & Variables & & Percentage \\
\hline \multirow[t]{2}{*}{ Gender } & Male & 72.5 & Marital status & Single & 23.5 \\
\hline & Female & 27.5 & & Married & 76.5 \\
\hline \multirow[t]{5}{*}{ Age } & $18-24$ years & 11.8 & Education & School education & 9.8 \\
\hline & $25-34$ years & 15.7 & & Graduate & 51.0 \\
\hline & $35-44$ years & 43.1 & & Post graduate & 19.6 \\
\hline & $45-55$ years & 21.6 & & Professional qualification & 11.8 \\
\hline & above 55 years & 7.8 & & Others & 7.8 \\
\hline \multirow[t]{4}{*}{ Income (RO) } & $\begin{array}{l}\text { Less than } \\
15,000\end{array}$ & 19.6 & $\begin{array}{l}\text { Sources of Income for } \\
\text { investment }\end{array}$ & Savings & 15.7 \\
\hline & $15,000-30,000$ & 52.9 & & $\begin{array}{l}\text { Money extracted from } \\
\text { business }\end{array}$ & 23.5 \\
\hline & $30,000-45,000$ & 21.6 & & Personal borrowing & 9.8 \\
\hline & Above 45,000 & 5.9 & & Inherited amount & 9.8 \\
\hline \multirow{4}{*}{$\begin{array}{l}\text { Expected } \\
\text { return }\end{array}$} & Less than $6 \%$ & 15.7 & & Bank finance & 15.7 \\
\hline & $\begin{array}{l}\text { between } 6 \% \text { - } \\
10 \%\end{array}$ & 11.8 & & Income from regular sources & 15.7 \\
\hline & $\begin{array}{l}\text { between } 10 \% \text { - } \\
15 \%\end{array}$ & 39.2 & & $\begin{array}{l}\text { Supports from friends and } \\
\text { relatives }\end{array}$ & 9.8 \\
\hline & above $15 \%$ & 33.3 & & & \\
\hline
\end{tabular}

Source: Survey data (2019) 
Gender is an important factor for the study and it describes the level of risk tolerance and investment behaviour. The present study finds more respondents belong to the male category with 72.5 percent, whereas the female occupies 27.5 percent. Though, the female contributions were found less compared to men investors, it is noteworthy that the approximately 30 percent of the investors that were female indicates that the women are involved in the fund management. Also, as it is earlier noted, the majority of the respondents are married, which means that the middleage groups are getting more involved in investment activities compared with the older groups infers; perhaps, this could be considered to be the ideal time to start building their investment portfolios. Additionally, it is observed that more than half of the sample respondents are graduates and the second position occupied by post-graduation.

The incomes from all sources are the important factor which decides the investment opportunity of individual investors. About half of the respondents belong to the middle income group within the range between RO 15,000 RO 30,000. The sources of income play a crucial role in deciding the investment avenues. The study reveals that the money extracted from business holds the first position and savings, bank finance and income from regular sources come next to the top with 15.7 percent. The majority of the respondents expect the return between 10 to 15 percent. This can be achieved only through the proper investment decisions.

\section{Behavioural factors and Investment decision}

Table 2 shows the Kaiser-Meyer-Olkin Measure of Sampling Adequacy which identifies the proportion of variance in the variables that may cause by new factors and its statistic varies between 0 and 1 . The below tables represents Kaiser-Meyer-Olkin Measure of Sampling Adequacy score of 0.773 shows high level of data adequacy. Also the chisquare value of 450.304 with the significant level of 0.000 , that is, $\mathrm{P}<0.05$.

Table 2. KMO and Bartlett's Test

\begin{tabular}{lll}
\hline Kaiser-Meyer-Olkin Measure of Sampling Adequacy. & .773 \\
\hline Bartlett's Test of Sphericity & Approx. Chi-Square & 450.304 \\
\cline { 2 - 3 } & Df & 91 \\
\cline { 2 - 3 } & Sig. & .000 \\
\hline
\end{tabular}

Source: Survey data (2019)

Table 3 identifies the variance identified with 14 variables of investors' behavioural factors. The communalities imply that the level of significant ranges between $49.8 \%$ and $90.9 \%$. Hence, it is concludes that the grouping variable factors is significant and meaningful. 
Table 3. Communalities

\begin{tabular}{|c|c|c|}
\hline & Initial & Extraction \\
\hline Confident on my decisions & 1.000 & .647 \\
\hline Satisfied with my decision & 1.000 & .697 \\
\hline Specific skills and experience & 1.000 & .585 \\
\hline Do technical analysis & 1.000 & .909 \\
\hline Indicator for future & 1.000 & .717 \\
\hline Analyst recommendations & 1.000 & .898 \\
\hline Conflict with analyst & 1.000 & .891 \\
\hline Company information affect my decision & 1.000 & .832 \\
\hline Friends and colleagues recommendations & 1.000 & .720 \\
\hline Borrow and invest & 1.000 & .736 \\
\hline Use past price movement & 1.000 & .648 \\
\hline Daily price fluctuations & 1.000 & .862 \\
\hline Use of charts, patterns and trends & 1.000 & .839 \\
\hline Use of company information & 1.000 & .498 \\
\hline
\end{tabular}

Source: Survey data (2019)

The principal component analysis determines that the components extracted is equal to the variables analysed the number of these variables worth enough and meaningful for factor rotations. The commonly used method to retain the components for rotation is Eigen value. The scree plot test identifies the break between components of small and larger Eigen values. The Varimax rotation method is standard rotation method. There are four components that have sufficient data variances and qualified for one Eigen value criterion. Based on the study result, there are four components seems to explain to the extent of $74.85 \%$ of the total variance and the remaining are explained by the remaining factors.

Table 4. Components and Variance Explained

\begin{tabular}{llll}
\hline Components & Eigenvalues & \% of Variance & Cumulative \% \\
\hline Component 1 & 4.956 & 35.402 & 35.402 \\
\hline Component 2 & 2.963 & 21.167 & 56.569 \\
\hline Component 3 & 1.344 & 9.598 & 66.167 \\
\hline Component 4 & 1.215 & 8.679 & 74.846 \\
\hline
\end{tabular}

Source: Survey data (2019) 
From Table 4 and Figure 2, evidence is shown that there are four components were significant enough to retain for rotation. Scree plot is a tool to identify the important factors in the graphical form of representation, which was coined by Cattell in 1966. Figure 2 shows that the results are almost flat after the fourth important factors. It can be inferred that these four factors explain the major investment behavioural bias affecting the investment decision of the investors.

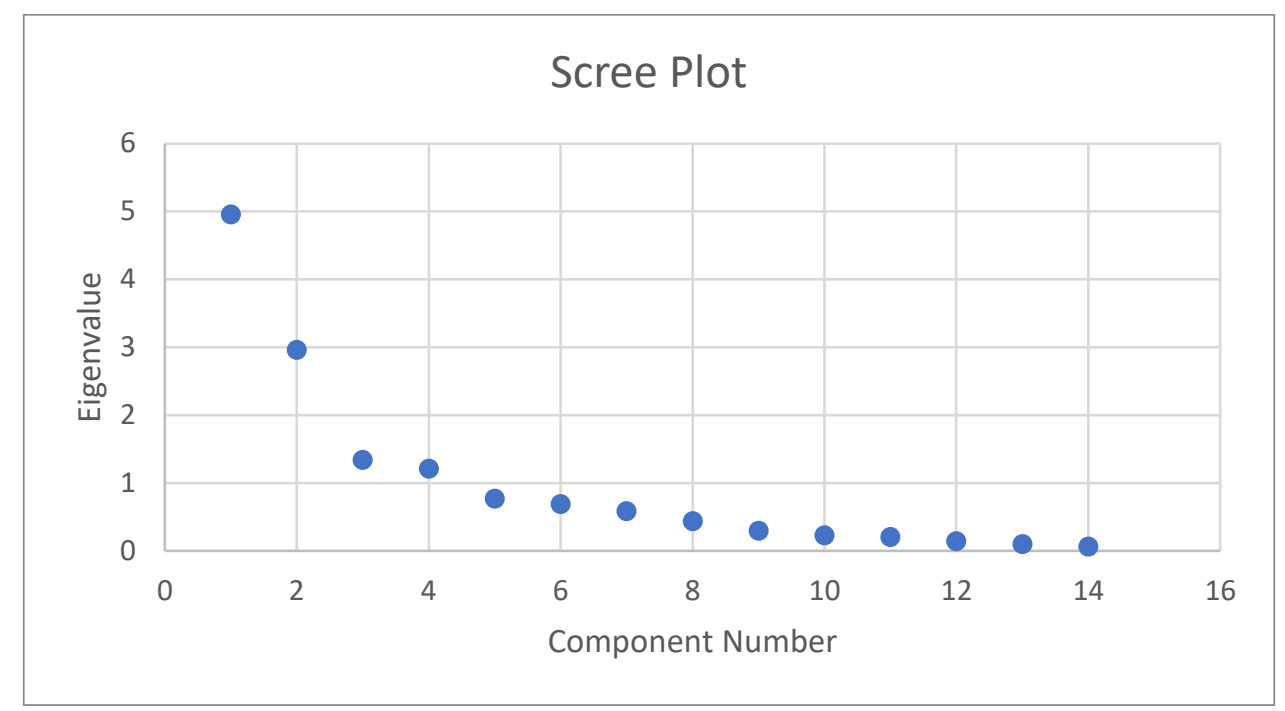

Source: Survey data (2019)

Figure 2. Scree Plot Four Factors 
Table 5. Factors extracted using Principal Component Analysis

\begin{tabular}{|c|c|c|c|c|}
\hline & \multicolumn{4}{|c|}{ Component } \\
\hline & 1 & 2 & 3 & 4 \\
\hline Company information affect my decision & .862 & & & \\
\hline Borrow and invest & .816 & & & \\
\hline Friends and colleagues recommendations & .810 & & & \\
\hline Satisfied with my decision & .805 & & & \\
\hline Specific skills and experience & .709 & & & \\
\hline Indicator for future & .792 & & & \\
\hline Use past price movement & .615 & & & \\
\hline Do technical analysis & & .879 & & \\
\hline Analyst recommendations & & .873 & & \\
\hline Conflict with analyst & & .872 & & \\
\hline Daily price fluctuations & & & .802 & \\
\hline Use of charts, patterns and trends & & & & .559 \\
\hline Use of company information & & & & .410 \\
\hline
\end{tabular}

Source: Survey data (2019)

The internal thinking and feeling and social factors such as friends, relatives information are determinants in investment decision-making. Specifically, seven main factors, namely, overconfidence, representation bias [heuristic factors], regret aversion, mental accounting [prospect factors], volume of trade and market information [herding behaviour], and movement of market prices [rationality factor] were found to be present in the MSM. Hence, it is inferred that these variables are influential more than other factors in the investment decision-making process of the average Omani investor context. This result supported the existing study conducted in Pakistani context by Mahmood et al (2016) in terms of Heuristic and Herding factors. Specifically, Heuristics and Herding were found to be positively related to investment performance, but Prospect is negatively related in the Pakistani context, whereas it is positively affects in the Oman context. The current study proves that the prospect also the important factor which decides the behavior of investors as stated in the study conducted by Radha et al (2014) and Tripathi and Chattopadhyay (2013).

\section{Behavioural factors and Investment Strategy}

As it is earlier noted, the research problem covers the psychological factors of investment behaviour and its association on investment strategy. Five behavioural factors comprising 16 variables were ascertained using factor analysis. Five point Likert scales were used to collect the primary data from the respondents. In Table 4.6, the KaiserMeyer-Olkin measure of sampling adequacy identifies the proportion of variance in the variables that may cause by new factors and its statistic varies between 0 and 1. From the results in Table 6, the Kaiser-Meyer-Olkin Measure of Sampling Adequacy score of 0.717 shows high level of data adequacy. Also the chi-square value of 571.594 with the significant level of 0.000 , that is, $\mathrm{p}<0.05$. 
Table 6. KMO and Bartlett's Test

\begin{tabular}{lll} 
Kaiser-Meyer-Olkin Measure of Sampling Adequacy. & .717 \\
\hline Bartlett's Test of Sphericity & Approx. Chi-Square & 571.594 \\
\cline { 2 - 3 } & Df & 120 \\
\cline { 2 - 3 } & Sig. & .000 \\
\hline
\end{tabular}

Source: Survey data (2019)

Table 7 shows the variances identified with 16 variables of investors' behavioural factors. The communalities imply that the level of significant ranges between $41.1 \%$ and $91.7 \%$. Hence, it is concluded that the grouping variable factors is significant and meaningful.

Table 7. Communalities

\begin{tabular}{lll}
\hline & Initial & Extraction \\
\hline Expecting trend reversal & 1.000 & .917 \\
\hline Diversified portfolio & 1.000 & .809 \\
\hline Retirement as savings & 1.000 & .873 \\
\hline Invest on specific sectors & 1.000 & .915 \\
\hline Based on time horizon & 1.000 & .857 \\
\hline Analyst recommendations & 1.000 & .858 \\
\hline Friends and colleagues recommendations & 1.000 & .806 \\
\hline Company information affect my decision & 1.000 & .749 \\
\hline Price to earnings ratio & 1.000 & .822 \\
\hline Dividend policy & 1.000 & .411 \\
\hline Debt to equity ratio & 1.000 & .502 \\
\hline Return on investment & 1.000 & .735 \\
\hline Use past price movement & 1.000 & .759 \\
\hline Daily price fluctuations & 1.000 & .880 \\
\hline Use of charts, patterns and trends & 1.000 & .723 \\
\hline Use of company information & .694 \\
\hline Extraction Method: Principa Comp & & \\
\hline
\end{tabular}

Extraction Method: Principal Component Analysis.

Source: Survey data (2019)

The Varimax rotation method is a standard rotation method. Five components have sufficient data variance and are qualified for one Eigen value criterion. The study results displayed in Tables 8 and 9 provide evidence that the five components explain total variance to the extent of $76.31 \%$, while the remaining percentage (23.69\%) are explained by the remaining factors. Similarly, Figure 3 shows that the results are almost fat after the five important factors. Thus, it can be deduced that these five factors explain the major investment behavioural bias affecting the investment decision of the investors. 
Table 8. Components and Variance Explained

\begin{tabular}{llll}
\hline Components & Eigenvalues & \% of Variance & Cumulative \% \\
\hline Component 1 & 4.814 & 30.090 & 30.090 \\
\hline Component 2 & 3.310 & 20.689 & 50.780 \\
\hline Component 3 & 1.514 & 9.461 & 60.241 \\
\hline Component 4 & 1.414 & 8.839 & 69.080 \\
\hline Component 5 & 1.157 & 7.230 & 76.310 \\
\hline
\end{tabular}

Source: Survey data (2019)

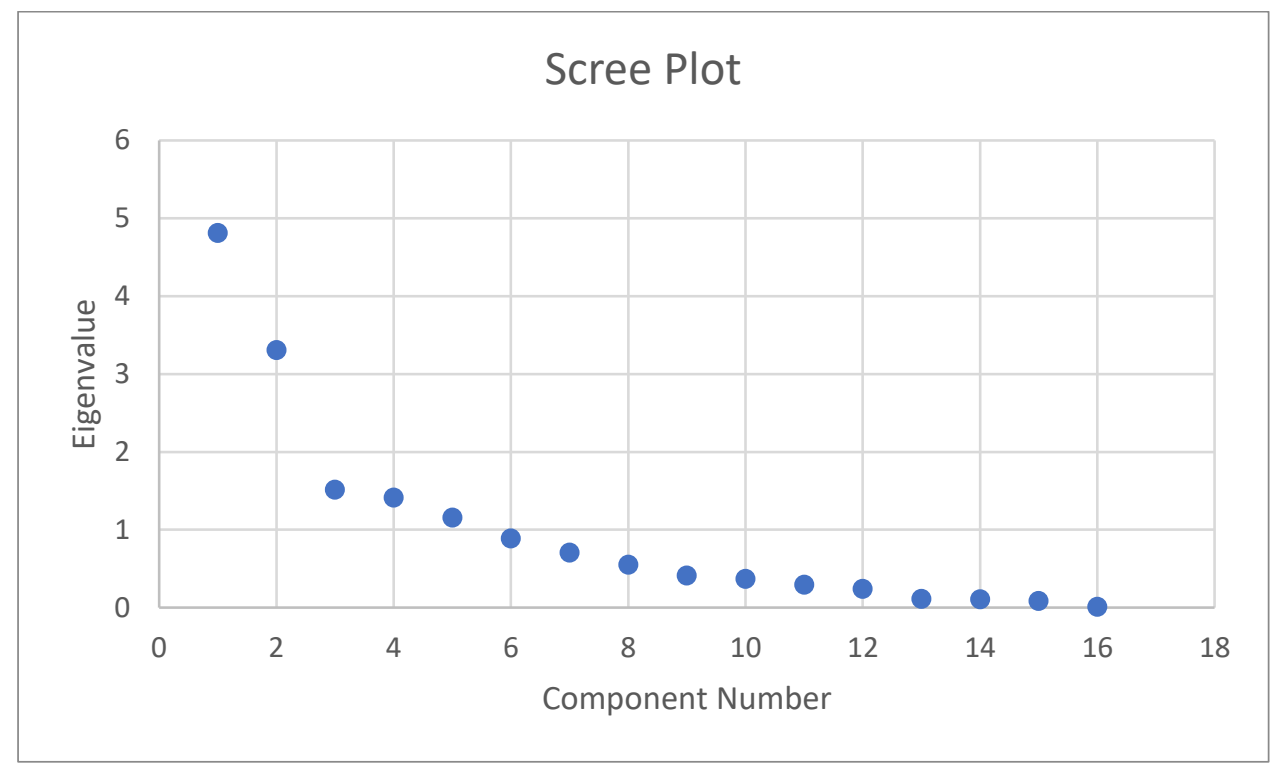

Source: Survey data (2019)

Figure 3. Scree Plot Five Factors 
Table 9. Factors extracted using Principal Component Analysis

\begin{tabular}{|c|c|c|c|c|c|}
\hline & \multicolumn{5}{|c|}{ Component } \\
\hline & 1 & 2 & 3 & 4 & 5 \\
\hline Diversified portfolio & .805 & & & & \\
\hline Retirement as savings & .853 & & & & \\
\hline Based on time horizon & .815 & & & & \\
\hline Friends and colleagues recommendations & .802 & & & & \\
\hline Company information affect my decision & .754 & & & & \\
\hline Return on investment & .686 & & & & \\
\hline Use past price movement & .618 & & & & \\
\hline Expecting trend reversal & & .828 & & & \\
\hline Invest on specific sectors & & .863 & & & \\
\hline Analyst recommendations & & .776 & & & \\
\hline Price to earnings ratio & & & .637 & & \\
\hline Dividend policy & & & .592 & & \\
\hline Debt to equity ratio & & & .548 & & \\
\hline Daily price fluctuations & & & & .822 & \\
\hline Use of company information & & & & & .606 \\
\hline Use of charts, patterns and trends & & & & & .601 \\
\hline
\end{tabular}

Source: Survey data (2019)

Generally, detailed information relating to the industry/sector, market and the particular company, as well as social factors such as friends, relatives market fluctuations, policies are among the factors which determines investment strategy. Specifically, there are five factors, namely, anchor, mental account state, movement of prices, volume of trade and the market information factor observed to be the main factors determining MSM traders' investment strategy. In these five factors, there are three factors namely anchoring, volume of trade and market information factors which are influencing factors in the Omani context, similar to the observation made by Mahmood et al (2016) in the Pakistani context. The presence of the other two major behavioural factors (mental accounting and movement of prices) were observed in the Indian context as noted by Tripathi and Chattopadhyay (2013). Hence, it can be deduced that these five variables, namely, anchoring, mental accounting, movement of prices, volume of trade and market information, are significantly influential in the investors' return optimization strategy thinking.

\section{Summary of key findings}

The present study is designed to identify the principal behavioural factors influencing investors' decisions and strategy in the MSM of the Sultanate of Oman. Four major results can be reported to have emerged from this study. 
First, the study has to some extent helped to revalidate the importance of businesses and investors pivotal social units in the financial ecosystem (Tripathi \& Chattopadhyay, 2013; Desai, 2019). This is shown from the detailed information relating to industries/sectors, market and the particular company, as well as social factors such as friends, relatives, market fluctuations, policies being found among the principal determinants of capital market investment strategy Second, the anchoring [heuristic factor], mental accounting [prospect factor], movement of prices [rationality factor], volume of trade and market information factors [herding factors] emerged as the five principal determinants of investment strategy in Oman context. Hence, it is inferred that these variables are influential more than other factors in the investment decision-making process and strategy of the average Omani investor. These findings are largely consistent with previous research, notably, Tripathi, M., and Chattopadhyay, T. (2013), Radha et al (2014), and Mahmood et al (2016).

Third, as suggested by previous research, notably Mahmood et al (2016) the present study revalidates irrational behavior as the product of certain cognitive and/or emotional biases in investment decision-making mentality. Fourth, and perhaps more specifically in the Omani context, current findings reveals that there is no gender variation in terms of capability in the decision-making process. This might be arguably considered as a new insight in the area of applied behavioral finance. Similarly, mental accounting was found to be relatively higher among married middle age group of Omani investors than other category of investors. These results could be useful to analysts and portfolio managers in better structuring clients' investment portfolios as the country looks forward to more stable post-carbon financial ecosystem.

\section{Conclusion and Recommendations}

The paper investigates the behavioural factors influencing investment' decision-making and strategy among security traders in Muscat Securities Market, Oman. Behavioural finance describes the variation among the individual investors behaviour during investment decision making process. The decision making process were influenced by various factors like heuristic, herd behaviour, prospects and rationality factors. The present study employed factor analysis to identify the influencing behavioural factors and the investment strategy. Consistent with previous studies conducted Tripathi and Chattopadhyay (2013), Radha et al (2014), and Mahmood et al (2016), among others, the present study reveals that the most dominant behavioural factors affecting investors' decisions are anchoring [heuristic factor], mental accounting [prospect factor], movement of prices [rationality factor], and volume of trade and market information factors [herding factors]. Additionally, no gender variation was observed in terms of capability in the decision making process; this finding would impact positively on government's financial inclusion strategy and reducing cost of capital in the long-term. Mental accountings were also found higher among married middle age group of investors than other category of investors.

The representative bias has more impact on the decision making process than other behavioural factors. The chart, technical analysis, financial statement analyses were also found to play notable role in the investment strategizing. Moderate investors tended to be more inclined to use the advantages of herd behaviour, while technical and fundamental analysis are the parameters for the aggressive investors. The trading frequency, price and volume analysis appeared to be statistically significant in terms of investment strategy. Optimum portfolio models are needed to guide investors and advisors in structuring the return on investment and more conservative portfolio selection. Advanced financial education could help the moderate investors during the optimal portfolio section process. Future research areas could explore the nexus between the identified behavioural factors in this paper with optimal return. For example, an appropriate risk model for portfolio selection can be developed for the Omani investor, taking the dominant behavioural factors from current findings into account. 


\section{References}

Al Balushi, Y., Locke, S., and Boulanour, Z. (2019). Determinants of the decision to adopt Islamic Finance: Evidence from Oman ISRA International Journal of Islamic Finance 2 (1), pp 6-26.

Alwathainani. A, (2012).Market reaction to an earnings shock: A test of conservatism effect. The Journal of Behavioural Finance and Economics. 2: 14-37.

Amar. K. C, (2013). Impact of behavioral finance in investment Decisions and strategies - a fresh approach. International Journal of Management Research and Business Strategy. Vol. 2. No. 2.

Athur. A. D, (2014). Effect of behavioural biases on investment decisions of individual investors in Kenya (Thesis). University Of Nairobi. Retrieved from http://erepository.uonbi.ac.ke/handle/11295/74832.

Avery, C. and Zemsky, P. (1998). Multidimensional uncertainty and herd behavior in financial markets. The American Economic Review. 88 (4): 724-748.

Baddeley, M., Curtis, A. and Wood, R. (2004). An Introduction to Prior Information Derived fromProbabilistic Judgments: Elicitation of Knowledge. Cognitive Bias and Herding (Special Publications)239:15-27.

Bessie`re. V., \& Elkemali. T., (2014). Does uncertainty boost overconfidence? The case of financial analysts' forecasts. Managerial Finance. 40 (3)

Bikhchandani, S., Hirshleifer, D. and Welch, I. (1992). A theory of fads, fashion, custom, and cultural change as informational cascades. Journal of Political Economy. 100 (5): 992-1026.

Bikhchandani.S., \& Sharma. S, (2001). Herd behaviour in financial markets. IMF Staff Papers. International Monetary Fund. 47(3): 279-310.

Black, F. (1986). Noise. Journal of Finance. 41(3): 529-543.

Blasco. N., Corredor. P., \& Ferreruela. S. (2012). Does herding affect volatility? Implications for the Spanish Stock Market. Quantitative Finance. 12: 311-327.

Bloomfield. R., Hales. J, (2002). Predicting the next step of a random walk: Experimental evidence of regime-shifting beliefs Journal of Financial Economics. 65: 397-414.

Boussaidi. R, (2013). Representativeness heuristic, investor sentiment and overreaction to accounting earnings: The case of the Tunisian stock market. Procedia - Social and Behavioural Sciences. Procedia-Social and Behavioural Sciences. 81: 9-21.

Chodorow-Reich, G., Nevov, P., and A. Simsek (2019, January) Stock market wealth and the real economy: a local labor market approach. Social Science Research Network SSRN Electronic Journal.

Cipriani, M. and Guarino, A. (2005). Herd behavior in a laboratory financial market. The American Economic Review. 95 (5): 1427-1443.

Coelho. L.A.G, (2014). Portfolio selection optimization under cumulative prospect theory — a parameter sensibility analysis. CEFAGE-UE Working Paper 2014/06.

Daniel, K., Hirshleifer, D. and Subrahmanyam, A. (1998). Investor psychology and security market under- and overreactions. Journal of Finance. 53 (6): 839-1885.

DeBondt, W.F.M. and Forbes, W.P. 1999. Herding in analyst earnings forecasts: evidence from the United Kingdom. European Financial Management. 5 (2): 143-163.

Desai, M. I. (2019). How finance works: The HBR guide to thinking smart about the numbers. Harvard Business Review Press

Dowie, G., \& Willows, G. (2016). An investigation of investors' estimates of returns earned and the effect of anchoring on these estimations. South African Journal of Accounting Research, 30(1), 29-40

Froot, K.A., Scharfstein, D.S. and Stein, J.C. (1992). Herd on the street: informational inefficiencies in a market with short-term speculation. The Journal of Finance. 47 (4): 1461-1484.

Frieder. L, (2004). Evidence on Behavioral Biases in Trading Activity. Working Paper. Los Angeles: University of California.

Friesen, G. and Weller, P. (2006). Quantifying cognitive biases in analyst earnings forecasts. Journal of Financial Markets. 9: 333-365.

Gervais, S. and Odean, T. (2001). Learning to be overconfident. Review of Financial Studies. 14:1-27.

Gopalakrishnan Chinnasamy, Nitha Siju \& Preeti Shrivastava. (2019), The Effects of Diversified Economic Activities on Sustainable Development: The Sultanate of Oman Perspective, International Conference on Banking, Finance and Business, College of Banking and Financial Studies Sultanate of Oman, ISBN:978-99969-824-2-2, April 2019.

Graham, J.R. 1999. Herding among investment newsletters: theory and evidence. The Journal of Finance. 54 (1): $237-268$.

Guo. Y.L, (2013). Can representativeness heuristic traders survive in a competitive securities market? Journal of Financial Markets. 16(1): 152-164.

Hirschey. M., \& Nofsinger. J., (2008). 'Investments: Analysis and Behaviour'. Tata McGraw Hill Publishing Company Limited, New Delhi. 14.

Holmes. R., P., Bromiley. C. Devers, T. Holcomb. \& McGuire. J. B, (2011). 'Management theory applications of prospect theory: accomplishments, challenges, and opportunities'. Journal of Management, 37: p. 1069-1107.

Jacob \& Ehret, 2006. Self-protection vs opportunity seeking in business buying behavior: an experimental study. Journal of Business \& Industrial Marketing. 21(2): 106-117. DOI 10.1108/10610420610651331.

Jains. D., \& Dashora. N, (2012). A study on impact of market movements on investment decision 'an empirical analysis with respect to investors in Udaipur, Rajasthan'. 
Jordan. B.D., \& Miller. T., (2008). Fundamentals of Investments (5th Ed.). New York, NY: McGraw-Hill.

Kahneman. D., \& Tversky. A. (1979). Prospect theory: An analysis of decision-making under risk. Econometrica, 47(2): 263291.

Kahuthu. D. G, (2011). Effects of herd behaviour on trading volume and prices of securities at NSE. MBA Research Project. University of Nairobi.

Kansal.P., \& Singh.S., (2015).Investment behaviour of engineers: An empirical study. Journal of Arts, Science and Commerce. 41(4).

Kengatharan. L, (2014).The influence of behavioural factors in making investment decisions and performance: Study on investors of Colombo Stock Exchange, Sri- Lanka. Asian Journal of Finance and Accounting. 6(1): 1-23.

Kim. K., \& Nofsinger, J., (2008). Behavioral finance in Asia. Pacific-Basin Finance Journal. 16(1-2): 1-7.

Kobberling. V., \& Wakker. P. P., (2005). An index of loss aversion. Journal of Economic Theory. 122(1): 119-131.

Kombo. D. K., \& Tromp. D. L. (2006). Proposal and Thesis Writing: An Introduction. Paulines Publications Africa. Nairobi.

Kothari C. R, (2011). Research Methodology. Methods and Techniques. New Age International Publishers. New Delhi. India.

Kusev, P., Purser, H., Heilman, R., Cooke, A. J., Van Schaik, P., Baranova, V., ... Ayton, P. (2017). Understanding Risky Behavior: The Influence of Cognitive, Emotional and Hormonal Factors on Decision-Making under Risk. Frontiers in psychology, 8, 102. doi:10.3389/fpsyg.2017.00102

Lakonishok, J., Shleifer, A. and Vishny, R.W. (1992). The impact of institutional trading on stock prices. Journal of Financial Economics. 32 (1):23-43.

Lowies. G. A., Hall. J. H., \& Cloete. C. E. (2013). "The influence of frame dependence on investment decisions made by listed property fund managers in South Africa", Journal of Economics and Behavioural Studies, 5(11), 805-814.

Lowies. G. A., Hall. J. H., \& Cloete. C. E. (2015). Heuristic-driven bias in property investment decision-making in South Africa. Journal of Property Investment \& Finance, 34(1) 51-67.

Luong. L. P., \& Thu Ha. D. T., (2011). Behavioral factors influencing individual investors' decision-making and performance: A survey the Ho Chi Minh Stock Exchange. Unpublished M.Sc. Thesis. Umeå School of Business. Umea. Sweden.

Lutje. T., (2009). To be good or to be better: asset managers' attitudes towards herding. Applied Financial Economics. 19 (10): $825-839$.

Luu. T. T., (2012). Marketing effectiveness and its precursors. Asia Pacific Journal of Marketing and Logistics. 24(1): 125-152.

Mahmood, Z., Kouser, R., Abbas, S. S., and Saba, I. (2016) The Effect of Hueristics, Prospect and Herding Factors on Investment Performance. Pakistan Journal of Social Sciences (PJSS) 36 (1). pp. 475-484

Markowitz. H., (1952). Portfolio selection. Journal of Finance. 7: 77-91.

Masomi. S. R., \& Ghayekhloo. S., (2011). Consequences of human behaviors' in Economic: The effects of behavioral factors in investment decision making at Tehran Stock Exchange. 2010.

Mason. J. R., \& Nelling. E., (2008). Herding behavior in Chinese stock markets: An examination of A and B shares. PacificBasin Finance Journal. 16(1-2): 61-77.

Mathuraswamy. P., \& Rajendran.G., (2015). Essence of rational investment in equity market: An empirical study. IJER Serials Publications. 12 (2): 439-449.

Miller. K. D., \& W. Chen., (2004). Variable organizational risk preferences: tests of the March-Shapira model. Academy of Management Journal. 47: 105-115.

Mochon, D. and Frederick, S. (2013). Anchoring in sequential judgments. Organizational Behavior and Human Decision Processes. 122 (1): 69-79.

Mugenda. O. M., \& Mugenda. A. G., (2009). Research Methods: Quantitative and Qualitative approaches. Nairobi Africa Centre for Technology Studies (ACTS) press. Nairobi. Nairobi Securities Exchange.

Mussweiler, T. and Strack, F. (2001). The semantics of anchoring. Organizational behavior and human decision processes. 86 (2): 234-255.

Ndiege. C. O., (2012). Factors influencing investment decision in equity stocks at the Nairrobi Securities Exchange among teachers in the Kisumu municipality, Kenya. Masters of Business Administration, University of Nairobi.

Nofsinger \& Richard. (2002). Individual investments behaviour. New York. McGraw-Hill.

Nofsinger. J. R., (2001). Investment madness: how psychology affects your investing and what to do about it. USA: Pearson Education.

Nunnally. J. C., (1978). Psychometric theory (2nd Ed.). New York: McGraw-Hill.

Osmond. I. C., Adebayo. O. O., Adesiyan. O. S., \& Moronke O. M., (2013). Factors Affecting the Usage of Major Heuristics in Nigeria Property Investment Valuation. Journal of Sustainable Development Studies. 4(2): 114-133.

Oso. W. K., \& Onen. D., (2009). A guide to writing research proposal and report. A handbook for beginning researchers. Revised Edition. Jomo Kenyatta Foundation.

Parikh. P., (2011). Value Investing and Behavioral Finance. New Delhi: Tata Mcgraw Hill.

Radha, K. S., Goyal, R., and Sharma, A. (2014) Study of factors influencing investment decision of households in Oman. Conference paper at 2nd International Conference on 'Technological and Management Advances in the New Age Economy: An Industry Perspective’ 1st March 2014 at Mangalmay Institute, Greater Noida, India.

Razek. Y.H., (2011). An overview of behavioural finance and revisiting the behavioural life cycle hypothesis. The IUP Journal of Behavioural Finance, VIII (3): 7-24. 
Rekik. Y.M., \& Boujelbene. Y., (2014). Evolutionary finance approach: Literature survey. IOSR Journal of Economics and Finance, 3(1): 44-53.

Ritter. J. R., (2003). Behavioral finance. Pacific-Basin Finance Journal. 11(4): 429-437.

Rose. W., (2003). Development of Nairobi Stock Exchange: A historical perspective. KIPPRA Discussion paper no 27.

Scharfstein. D., \& Stein. J., (1990). Herd behaviour and investment. American Economic Review. 80: 465-479.

Schmidt. I., \& Zank. H., (2012). A genuine foundation for prospect theory. Journal of Risk and Uncertainty. 45(2): 97-113.

Schmidt. U., Starmer. C., \& Sugden. R., (2008). Third-generation prospect theory. Journal of Risk and Uncertainty. 36(3): 203223.

Sekaran. U., (2003). Research methods for business: A skill building approach. (4th Ed.). London: John Wiley \& Sons Inc.

Shah. K. A., \& Oppenheimer. M.D., (2008). Heuristics made easy: An effort reduction framework. Psychology Bulletin. 134(2): 207-222.

Shefrin. H., (2002). Beyond Greed and Fear: Understanding Behavioural Finance and the Psychology of Investing. Oxford University Press. ABD. p.18.

Shikuku. R.M., (2012). The effects of behavioural factors on investment decision making by unit trust companies in Kenya. MBA University of Nairobi.

Sias, R.W. (2004). Institutional herding. Review of Financial Studies. 17 (1): 165-206.

Simonsohn, U. and Ariely, D. (2008). When rational sellers face nonrational buyers: evidence from herding on eBay. Management Science. 54 (9): 624-1637.

Singh. A., (1997). Financial liberalization, stock markets and economic development. The Economic Journal. 107(442): 771782.

Singh. J. E., \& Shivaprasad, (2018). Review of Behavioral Finance: Insights into Irrational Minds and Market, International Journal for Research in Engineering Application \& Management (IJREAM) ISSN: 2454-9150 Vol-03. Issue-12.

Sleeth-Keppler, D. (2013). Taking the high (or low) road: a quantifier priming perspective on basic anchoring effects. The Journal of Social Psychology. 153 (4): 424-447.

Statman. M., Fisher. K., \& Anginer. D., (2008). Affect in a behavioural asset-pricing model. Financial Analysis Journal. 74(2): 20-29.

Spyros S., (2013). Herding in financial markets: a review of the literature. Review of Behavioral Finance. 5 (2):175-194. DOI 10.1108/RBF-02-2013-0009 .

Thaler, R. H. (1985). Mental accounting and consumer choice. Marketing Science.3: 99-214.

Thaler. R. H., (2008). Mental Accounting and Consumer Choice. Marketing Science. 27(1). 15-25.

Todd. P. M., (2000). Ecological rationality and its contents. Thinking and Reasoning, 6, 375-384.

Tripathi, M., and Chattopadhyay, T. (2013) Study of behavioural dimensions of perceived risk of investment of financial experts and laymen in equity mutual funds in India. Journal of Commerce \& Accounting Research, 2 (4), pp. 10-27.

Wakker. P. P., (2010). Prospect theory: For risk and ambiguity: Cambridge University Press.

Walter. A., \& Weber. M. F., (2006). Herding in the German mutual fund industry. European Financial Management, 12(3). 375406.

Waweru. N.M., Munyoki. E., \& Uliana. E. (2008). The effects of behavioral factors in investment decision-making: A survey of institutional investors operating at the Nairobi Stock Exchange. International Journal of Business and Emerging Markets. 1(1): 24-41.

Werth. L., Strack. F., \& Forster. J., (2002). Certainty and uncertainty: The two faces of hindsight bias. Organizational Behavioural and Human Decision Processes. 87(2): 323-341.

Wilson, T.D., Houston, C.E., Etling, K.M. and Brekke, N. (1996). A new look at anchoring effects: basic anchoring and its antecedents. Journal of Experimental Psychology: General. 125 (4): 387-402.

Winchester. D. D., Huston. S.J., \& Finke. M.S., (2011). Investor Prudence and the Role of Financial Advice. Journal of Financial Service Professionals.

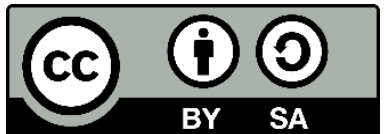

(C) 2019 by the authors. Licensee ACRN Publishing, Austria, Editor in Chief Prof. Dr. Othmar M. Lehner. This article is an open access article distributed under the terms and conditions of the Creative Commons Attribution (CC BY SA) license (https://creativecommons.org/licenses/by-sa/4.0/) 